\title{
Development of Electrochemical Immunosensor for the Detection of Human interleukin-37 for Potential Diabetes Diagnosis
}

\author{
Ge Zhang ${ }^{1,2}$, Wei Huang ${ }^{2}$, Haojun $\mathrm{An}^{2}$, Chunjun $\mathrm{Li}^{3}$ and Demin $\mathrm{Yu}^{3, *}$ \\ ${ }^{1}$ Tianjin Medical University, Tianjin, 300070, P.R. China \\ ${ }^{2}$ Tangshan Worker Hospital, Tangshan, 063000, P.R. China \\ ${ }^{3}$ Metabolic Disease Hospital of Tianjin Medical University, Tianjin, 300070, P.R. China \\ *E-mail: deming tianjing@qq.com
}

doi: $10.20964 / 2017.03 .04$

Received: 25 November 2016 / Accepted: 28 December 2016 / Published: 12 February 2017

\begin{abstract}
Interleukin-37 (IL-37) has been sensitively detected by the electrochemical immunosensors owing to the dual amplification of AuNP-PDA (gold nanoparticles and Polydopamine). PDA was employed as an immobilization biomolecules not only to construct a sensor platform but also to label signal. The amplification of the sensitivity can be achieved by the employment of particular AuNP-PDA platform and AuNP-PDA@graphene modified by HRP-Ab2 (horseradish peroxidase and antibody). The response of IL-37 was evaluated by the determination of amperometry, and the linear range is starting from $4 \mathrm{pg} / \mathrm{mL}$ to $800 \mathrm{pg} / \mathrm{mL}$ and the detection limit was very low $(0.8 \mathrm{pg} / \mathrm{mL})$. The performance of immunosensors for detecting IL-37 in human serum was compared with assays of standard ELISA. Furthermore, the diagnosis of clinic diabetes would be potentially achieved by this well-defined immunosensor.
\end{abstract}

Keywords: Immunosensor; Human interleukin-37; Diabetes diagnosis; Polydopamine; AuNP

\section{FULL TEXT}

(C) 2017 The Authors. Published by ESG (www.electrochemsci.org). This article is an open access article distributed under the terms and conditions of the Creative Commons Attribution license (http://creativecommons.org/licenses/by/4.0/). 